\title{
Use and efficacy of bone morphogenetic proteins in fracture healing
}

\author{
Suzanne N. Lissenberg-Thunnissen • \\ David J. J. de Gorter • Cornelis F. M. Sier • \\ Inger B. Schipper
}

Received: 12 March 2011 / Accepted: 4 June 2011 /Published online: 23 June 2011

(C) The Author(s) 2011. This article is published with open access at Springerlink.com

\begin{abstract}
Purpose This review evaluates the application of bone morphogenetic proteins (BMPs) in delayed bone repair, aiming at a broad audience from clinicians to scientists. Next to an overview of the role of the different BMPs, their antagonists and their current applications, special attention is focused on new scientific developments improving the effects of BMP-based therapy for bone repair.

Methods Publication searches in PubMed and Embase revealed 850 relevant articles on the criteria 'BMP' AND 'bone repair' (as of May 2011). The abstracts were carefully reviewed and papers were selected according to the content.

Results The resulting publications showed that BMP-2 and BMP-7 are clearly the most extensively evaluated BMPs, in general with positive results on bone healing, comparable to the use of unspecific preparations such as autologous bone grafts or platelet-rich plasma.

Conclusions Although the efficacy of BMPs as stimulators of bone repair has been demonstrated in model systems and clinical studies, the use of BMPs to enhance fracture healing in the clinical setting is still controversial. Issues such as when, where and how much of which BMP is the most effective and profitable to use still have to be elucidated. But optimisation of the BMP products used in
\end{abstract}

S. N. Lissenberg-Thunnissen • C. F. M. Sier $(\bowtie) \cdot$ I. B. Schipper Department of Surgery-Traumatology,

Leiden University Medical Center,

Albinusdreef 2,

2333 ZA Leiden, The Netherlands

e-mail: c.f.m.sier@lumc.nl

D. J. J. de Gorter

Department of Molecular Cell Biology,

Leiden University Medical Center,

Leiden, The Netherlands combination with cheaper production methods will inevitably stimulate the clinical use of BMPs for bone fracture healing in the near future.

$\begin{array}{ll}\text { Abbreviations } \\ \text { ALP } & \text { Alkaline phosphatase } \\ \text { BMP } & \text { Bone morphogenetic protein } \\ \text { BAMBI } & \text { BMP and activin membrane-bound inhibitor } \\ \text { BMP-RI } & \text { BMP receptor type I } \\ \text { BMP-RII } & \text { BMP receptor type II } \\ \text { CDMP } & \text { Cartilage-derived morphogenetic protein } \\ \text { CIZ } & \text { Cas-interacting zinc finger protein } \\ \text { CRIM1 } & \text { Cysteine-rich motor neuron 1 } \\ \text { GDF } & \text { Growth and differentiation factor } \\ \text { HIF-1 } \alpha & \text { Hypoxia-inducible factor 1 } \alpha \\ \text { PRP } & \text { Platelet-rich plasma } \\ \text { PTH } & \text { Parathyroid hormone } \\ \text { rh } & \text { Recombinant human } \\ \text { Smurf } & \text { Smad ubiquitin regulatory factor } \\ \text { Smad } & \text { Combination of Sma and Mad } \\ \text { TGF- } \beta & \text { Transforming growth factor- } \beta \\ \text { Tsg } & \text { Twisted gastrulation } \\ \text { Wnt } & \text { Combination of Wg (wingless) and Int }\end{array}$

\section{Introduction}

The overall incidence of long bone fractures in the Western world is estimated to be between 300 and 400 individuals per 100,000 per year $[1,2]$. The majority of trauma-induced fractures in adults will heal within nine months [3]. For progressive union of a fracture, the factors combined in the so-called diamond concept need to be present: an adequate 
cellular environment, sufficient growth factors, a bone matrix and mechanical stability. Apparently $5-30 \%$ of the patients lack one of these factors, because they will develop complications during the healing process, leading to delayed union or even non-union of the fracture [4]. These complications may induce prolonged hospitalisation and secondary interventions with concomitant inconveniences and costs. Especially for those patients, but eventually for all patients with fractures, treatments that positively influence bone healing and subsequently shorten the time necessary for bone union are of great interest.

Healing of fractures and time to union can be improved by biophysical stimulation or by administration of biological substances, such as autologous bone grafts or plateletrich plasma (PRP). The optimal administration dose and the identity of the active substances in these preparations are largely unknown. Recent studies into the mechanism of fracture repair have resulted in the identification of more specific compounds for intervention. Examples are the parathyroid hormone (PTH), hypoxia-inducible factor $1 \alpha$ (HIF-1 $\alpha$ ), modulators of the Wnt signalling pathway and the bone morphogenetic proteins (BMPs) [5]. The administration of defined compounds instead of heterogeneous mixtures of proteins may result in better treatment options and could also offer financial advantages. Promising candidates are the BMPs, which were originally identified as the active components in bone extracts capable of inducing de novo bone formation at ectopic sites $[6,7]$. This review will focus on the application of recombinant human BMPs (rhBMPs) in bone repair.

\section{BMPs}

Eventhough earlier observations had been made, Urist published in 1965 the conclusive observations on the induction of cartilage and bone by demineralised segments of bone [6]. The osteoinductive activity was found to be induced by a family of proteins present in bone, which were named BMPs [8].

BMPs are a subfamily of the transforming growth factor$\beta$ (TGF- $\beta$ ) superfamily, also comprising activins and inhibins. Thus far, around 20 different proteins have been named BMP in humans, but not all members are truly osteogenic (Table 1). The bone-inducing BMPs can be divided into several subgroups, according to homology of their amino acid sequences [9, 10]. BMP-2 and BMP-4 comprise one subgroup; the second group consists of BMP5, BMP-6, BMP-7 and BMP-8, while BMP-9 and BMP-10 form the third osteogenic group $[9,11]$. The other members of the BMP family do not posses osteogenic properties. BMP-1 is actually a metalloprotease and not a member of the superfamily [12], whereas BMP-3 and BMP-13 func- tion as BMP antagonists/inhibitors rather than as BMPs $[13,14]$.

In bone, BMPs are produced by osteoprogenitor cells, osteoblasts, chondrocytes and platelets $[15,16]$. After their release, the extracellular matrix functions as a temporary storage for BMPs. The regulatory effects of BMPs depend upon the target cell type, its differentiation stage, the local concentration of BMPs, as well as the interactions with other secreted proteins [4]. BMPs induce a sequential cascade of events leading to chondrogenesis, osteogenesis, angiogenesis and controlled synthesis of extracellular matrix [10] (see Fig. 1).

The BMPs exert their effects through binding as dimers to type I and type II serine/threonine kinase receptors, forming an oligomeric complex (Fig. 2). The type II receptors are constitutively active and phosphorylated and consequently activate the type I receptors upon oligomerisation. Subsequently, the activated type I receptors phosphorylate intracellular effector proteins, the receptor-regulated Smads (RSmads), Smad1, Smad5 and Smad8. Upon activation, the Smads associate with the Co-Smad, Smad4, and translocate into the nucleus, where they associate with other transcription factors and bind promoters of target genes to control their expression [10, 17-20] (Fig. 1).

\section{BMP antagonists and modulators}

The activity of BMPs is locally regulated by a number of antagonists. High expression of BMP antagonists will negatively influence fracture healing. These antagonists can be subdivided into molecules that act extracellularly or intracellularly. Extracellular antagonists such as noggin, chordin, twisted gastrulation (Tsg), gremlin, follistatin and BMPER are cystine knot-containing proteins forming complexes with BMPs, thereby preventing them to bind their receptors [18, 19, 21-24]. Another secreted antagonist is BMP-3, which induces activation of a TGF- $\beta$ /activin-like pathway and as a consequence inhibits signalling by osteogenic BMPs and bone formation [18, 21, 25]. Inhibition of BMPs can also occur at the cell membrane. CRIM1, a transmembrane protein, with cysteine-rich repeats similar to chordin, regulates the rate of processing and delivery of BMPs to the cell surface [26]. The pseudo-receptor BAMBI (BMP and activin membrane-bound inhibitor) is a transmembrane protein of which the extracellular domain shares high sequence similarity with type I receptors, but which lacks the intracellular kinase domain and is thought to inhibit BMP signalling by interfering with receptor complex formation [27]. Endoglin (CD105) is a transmembrane coreceptor involved in the regulation of a number of members of the TGF- $\beta$ superfamily, including TGF- $\beta$ and BMPs. Down-regulation of endoglin results in decreased signalling 
Table 1 Overview of BMP characteristics
$G D F$ growth differentiation factor, $C D M P$ cartilage-derived morphogenetic protein

\begin{tabular}{lllll}
\hline Subfamily & BMP & Synonyms & Involved in & Refs. \\
\hline 1 & BMP-2 & BMP-2A & Bone and cartilage formation & {$[7,76]$} \\
2 & BMP-4 & BMP-2B & Teeth and bone formation & {$[76-78]$} \\
& BMP-5 & & Cartilage development & {$[79]$} \\
BMP-6 & Vgr-1 & Joints, liver & {$[80,81]$} \\
BMP-7 & OP-1 & Renal development, kidney & {$[82,83]$} \\
BMP-8 & OP-2 & Bone and cartilage formation & {$[84]$} \\
& & BMP-8B & & \\
BMP-9 & GDF-2 & CNS, liver, angiogenesis & {$[78,85-87]$} \\
& & Morphogenesis of the heart & {$[78,88]$} \\
BMP-10 & & Metalloprotease, cartilage development & {$[12]$} \\
BMP-1 & & BMP inhibitor, bone formation & {$[13]$} \\
BMP-3 & Osteogenin & & {$[20]$} \\
BMP-3B & GDF-10 & BMP inhibitor, tendons & {$[14]$} \\
BMP-13 & GDF-6, CDMP-2 & CNS & {$[78]$} \\
BMP-11 & GDF-11 & Tendons, cartilage & {$[89]$} \\
BMP-12 & GDF-7, CDMP-3 & Cartilage & {$[91]$} \\
BMP-14 & & Oocyte development & {$[92]$} \\
BMP-15 & GDF-9 & $?$ &
\end{tabular}

of BMPs, demonstrating a positive regulatory effect on BMP activity [28, 29]. Intracellular antagonists such as Smad6, Smad7 and Smad8b and Smurfl and Smurf2 intervene with the activation of R-Smads and/or facilitate their proteasomal degradation (Fig. 2). Furthermore, apart from its C-terminal phosphorylation by BMP type I receptors, Smad1 can be phosphorylated by the Erk, P38 and JNK MAP kinases and
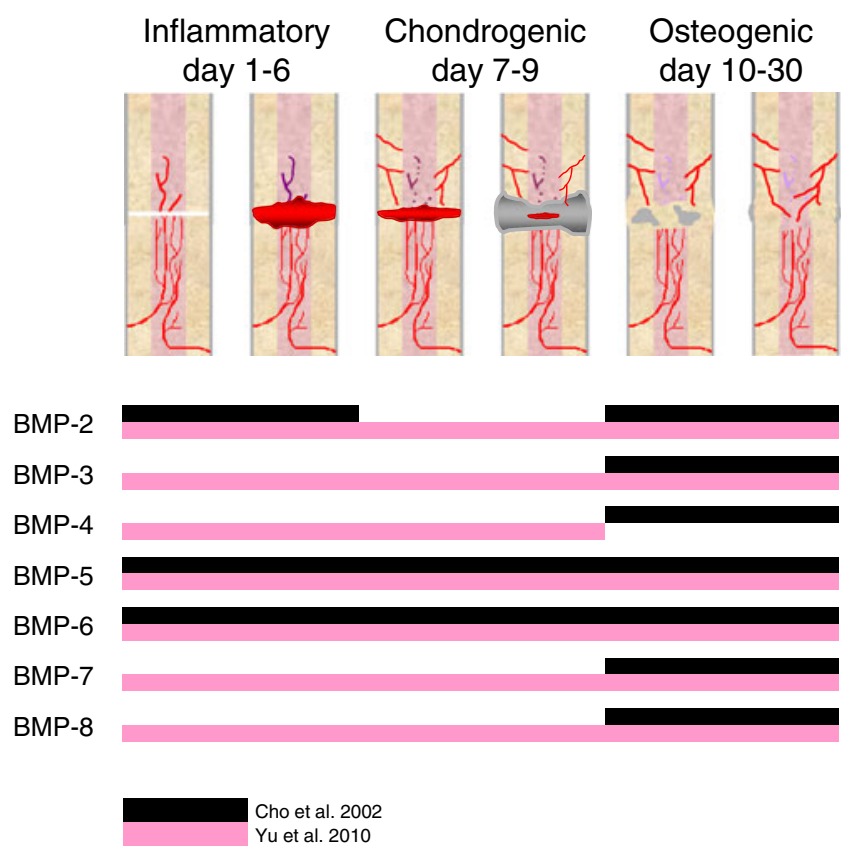

Fig. 1 Schematic overview of BMP expression during different stages of fracture healing $[74,75]$. The indicated days are dependent on the bone and fracture type subsequently by GSK-3, which results in cytoplasmic retention and increased proteasomal degradation of Smad1 [30, 31].

In conclusion, the mere presence of BMPs is no guarantee of efficient bone healing. Although the presence of BMPs is essential for a number of processes during bone healing, BMP-mediated bone formation strongly depends on the local presence of various BMP activity regulating inhibitors and stimulators.

\section{Treatment with BMPs}

\section{Clinical use of BMPs}

Based on various animal studies and preclinical trials, several clinical studies have been performed to demonstrate the efficacy of BMPs in accelerating bone regeneration and fracture healing [32-35]. The osteogenic potency of the $\mathrm{BMPs}$ requires a local and controlled delivery. Moreover, for clinical use of BMPs, their short half-life time should be taken into account. Several delivery systems have been developed to overcome this limitation [4, 36-38].

For clinical use rhBMP-2 (dibotermin alfa), with the product names InductOs ${ }^{\circledR}$ (UK) and InFUSE (US), is supplied within a bovine collagen sponge carrier, allowing slow release over time. This combination has been thoroughly investigated and was approved by the US Food and Drug Administration (FDA) in 2004 [39]. Govender et al. evaluated the effects of rhBMP-2 treatment in 450 patients with open tibial fracture in a prospective setup [32]. 
Fig. 2 Regulation of the BMP signalling pathway during bone formation. 1 BMP binds to BMP receptor type II (BMP-RII). 2 BMP/BMP-RII complexes with BMP receptor type I (BMP-RI), which is then phosphorylated. 3 BMP-RI phosphorylates the regulatory Smad1, Smad5 and Smad9, after which a complex is formed with Smad4. The complex is transported to the nucleus and the regulation of target genes occurs, leading to bone formation. Further regulation of the signalling pathway takes place at various levels. 4 Extracellular BMP inhibitors, e.g. chordin, noggin, Tsg, gremlin, follistatin and BMPER. 5 Receptor antagonists, e.g. BMP-3, BMP-13. 6 Membrane pseudoreceptors, e.g. BAMBI, CRIM1, and co-receptors, e.g. endoglin. 7 Intracellular inhibitors, e.g. Smad6, Smad7, Smad8b, Smurf1, Smurf2

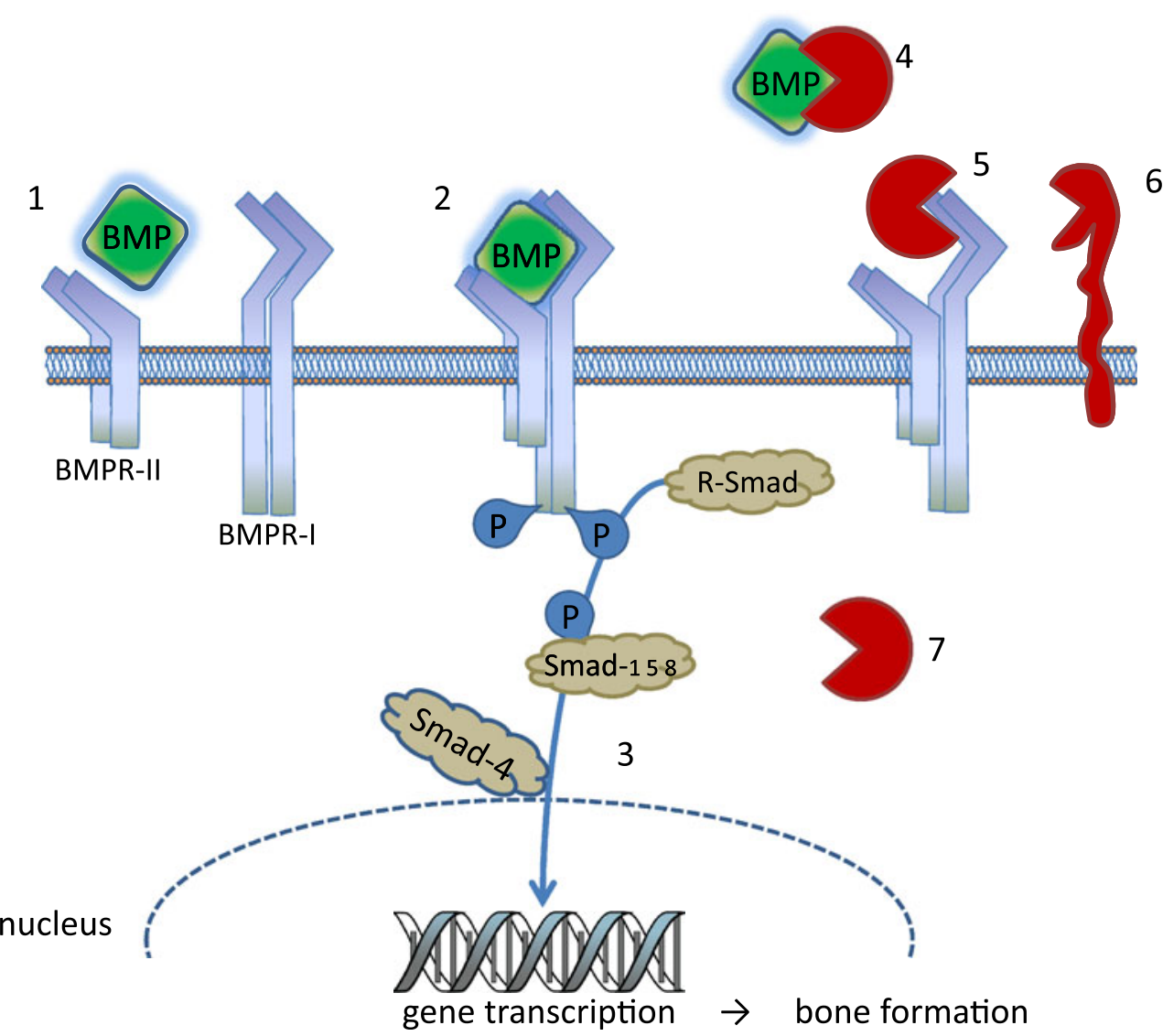

Implantation of rhBMP-2 in a collagen sponge led to a significantly higher union rate, reduced time to union, improved wound healing, reduced infection rate and fewer secondary invasive interventions in the group treated with rhBMP-2.

The other clinically used BMP, rhBMP-7, with the brand names Osigraft ${ }^{\circledR}$ (UK) and OP-1 Putty (US), is supplied in $1 \mathrm{~g}$ bovine collagen carrier in granular form [40]. In small but randomised trials, the positive effect of rhBMP-7 on repair of scaphoid non-unions and fibular defects was demonstrated [41, 42]. Administration of rhBMP-7 showed better formation of bone and bridging of the segmental defects compared to controls. Giannoudis and Tzioupis evaluated the type of indications and the efficacy for treatment with rhBMP-7 [34]. A variety of clinical conditions, such as persistent fracture non-unions, augmentation of periprosthetic fracture treatment and osteotomies, enhancement of fracture healing following acetabular reconstruction, distraction osteogenesis, free fibular graft and arthrodesis of joints, were treated with rhBMP-7. Of 653 cases, the overall success rate was $82 \%$ (535 cases) [34]. Ristiniemi et al. treated 20 patients with distal tibial fractures that had been stabilised with external fixation with rhBMP-7 in bovine collagen [43]. Healing of the fracture was compared with that of 20 matched patients who received the same treatment only without BMP-7. In the patients treated with rhBMP-7, significantly more fractures had healed and time to union was shorter. They concluded that BMP-7 enhanced the union of distal tibial fracture.

The potency of rhBMP-2 and rhBMP-7 has recently been compared, in vitro and in vivo [44]. In vitro, both agents increased the alkaline phosphatase (ALP) production, which indicated osteogenic differentiation, but the production of ALP was markedly higher in the rhBMP-2 group than in the rhBMP-7 group. However, in vivo rhBMP-7 produced significantly larger ossicles, with significantly more bone and mineral content. Other in vivo studies showed that rhBMP-2 could be more potent than rhBMP-7 [23]. These contradictory results could be the effect of the different working mechanisms and of the different time frames of the single BMPs during the process (see Fig. 1) and therefore also depend on the scaffold in which the BMPs are administrated [10]. These problems could be circumvented by using more sophisticated scaffolds, which could even allow the use of both BMPs in an optimised time frame, with early release of BMP-2 followed by BMP-7 in a later stage [37].

Platelets contain considerable amounts of BMPs and the treatment of fractures with PRP is at least in part based on BMPs [15]. Calori et al. showed, however, that the application of rhBMP-7 as a bone-stimulating agent is superior compared to that of PRP with regard to their clinical and radiological efficacy [33]. 
Although various animal and preclinical studies have demonstrated the powerful osteoinductive properties of single recombinant human BMPs, the results of clinical trials with rhBMP-2 and rhBMP-7 are less impressive. This was also concluded in a recent Cochrane review, in which similar times for fracture healing between controls groups and groups treated with BMP-2 or BMP-7 were demonstrated [45]. Several possible explanations have been suggested, such as rapid tissue clearance and lack of responding cells at time of administration [46]. Some of the (endogenous) factors possibly contributing to the limited efficacy of BMP administration will be discussed in the "Blocking antagonists" section.

\section{Adverse effects of BMPs}

Several side effects have been suggested for the use of rhBMPs in fracture healing. Especially with regard to the supra-physiological doses, ectopic bone formation and stimulation of cancer cells are being studied. Recombinant BMP-2 has recently been shown not to be associated with pancreatic cancer in a study with more than 90,000 patients [47]. The most frequently described adverse effect is the development of antibodies against the administrated rhBMPs or against the bovine collagen carrier [32, 38]. This immunogenic reaction was found to be positively correlated with higher doses of BMP and collagen. No correlation between the immune response to bovine collagen and treatment failure was demonstrated, and no clinical manifestations of an immune response or allergies to bovine collagen were found. Side effects of BMP-2 such as ectopic bone formation in fracture treatment and critical soft tissue swelling for cervical spine fusions have also been observed. However, these were associated with the use of very high BMP doses in animal studies, varied among species, and ultimately remodelling to the normal bone contour occurred. Nonetheless, BMPs remain a potent treatment option to enhance fracture healing with low risk of adverse events if correctly used. After administration of rhBMPs, biological negative feedback loops are activated resulting in the production of BMP antagonists and culminating in diminished rhBMP activity, probably influencing therapeutic efficacy. The historical approach of administrating larger amounts of BMPs in an effort to enhance the efficacy might result in the opposite effect. Recent studies using sophisticated biomaterials as BMP carriers show better results with lower doses, corresponding more with physiological concentrations [48].

\section{Cost-effectiveness of rhBMPs}

Next to the side effects, the use and costs of rhBMPs are also under debate. BMPs are delicate to handle, expensive to manufacture and supra-physiological doses are used, resulting in high costs. Nevertheless several studies indicate that despite these costs the clinical use of BMP-2 and BMP7 is still recommended from a health economic point of view [49, 50]. Cost reductions for hospitals are mainly related to shorter surgery time due to the absence of the bone grafting procedure and faster discharge of the patient. For the patients treated with rhBMP-2, the time to return to work is significantly reduced, as is the risk of revision surgery [49]. In a comparative study BMP-7 treatment was found to be as efficient as autologous bone graft, but the average cost was $6.78 \%$ higher, mainly due to the price of BMP-7 [50]. A systematic review on the clinical and costeffectiveness of BMPs concluded that the use of BMPs was associated with a reduced operating time, improvement in clinical outcomes and a shorter hospital stay as compared to the use of autograft [51]. The proportion of secondary interventions tended to be lower in the BMP group than in the controls, but this was not statistically significant. In non-unions, there is no evidence that BMP treatment is more or less effective than bone grafts; however, it is currently used when bone grafts and other treatments have failed. According to the results of economic evaluation, for spinal fusion the use of BMP is unlikely to be cost-effective [51]. As for any novel treatment, further studies, preferably randomised, controlled blinded and with sufficient power and proper controls, are needed to assess the clinical effectiveness of the use of BMPs for bone union [52-54]. These studies are currently being performed, e.g. BMP-7 for tibial fractures in Ghent, Belgium (NCT00551941). The issue of cost-effectiveness should be discussed afterwards.

One important issue, the expensive manufacturing of BMPs, can be overcome by new and cheaper production methods, such as the method described by von Einem et al. for rhBMP-2 [55]. Another alternative could be the use of inexpensive compounds that locally stimulate the induction of BMPs. Statins have been shown to increase the expression of BMP-2 [56]. Locally applied simvastatin improved fracture healing in a rat model similar to the effect of BMP-2 [57]. Statins are relatively cheap and welltested drugs and their BMP-stimulating properties may contain new possibilities in terms of fracture healing. In this respect, the recently discovered soluble form of the BMP activity-enhancing co-receptor endoglin also deserves future investigation [28].

\section{Blocking antagonists}

Because rhBMP treatment has some disadvantages, the quest for alternative treatment is still ongoing. Blocking of the function of BMP antagonists may provide such an alternative. By inhibiting BMP antagonists an environment can be created in which the rhBMP therapy will be more 
effective. The best effects will be reached by inhibition of factors antagonising BMP activity at the level of the callus [23]. To date, very little literature is available about the manipulation of BMP antagonists to promote bone healing in humans. The BMP inhibitor $\alpha 2$-HS-glycoprotein (Ahsg) was found to control the osteogenic potency of ectopically applied BMP [58]. The BMP antagonist noggin showed potential clinical applications in a mouse model [25]. Noggin-suppressed osteoblasts are suggested as a method of treatment to avoid the need for exogenous application of BMPs [59]. The use of inhibiting monoclonal antibodies against sclerostin, an indirect BMP antagonist [60], has shown increased bone formation in rodents and primates, suggesting a therapeutic role in osteoporosis [24]. By manipulating the balance with antagonists, endogenous BMP activity can be up-regulated throughout the process of fracture healing, avoiding issues of timing, dose and delivery. These preliminary findings suggest that antagonists may have a therapeutic role in regulating the size or shape of BMP-containing implants and in preventing heterotopic ossification.

\section{Application of other BMP family members}

Several studies investigating the potential of BMPs indicated that other members of the BMP family, different than the currently used BMP-2 and BMP-7, might provide attractive alternatives for fracture treatment (Table 2). In vitro, most human BMPs were able to stimulate osteogenesis in mature osteoblasts, but BMP-6 and BMP-9 were more efficient in driving osteoblast differentiation of mesenchymal stem cells than BMP-2 and BMP-7 [17]. BMP-6 and BMP-9 were also found to be more effective osteogenic factors in a mouse model for bone regeneration compared to BMP-2 and BMP-7 [61]. Moreover, BMP-6, BMP-9 and BMP-4 showed more osteogenic potential than the approved rhBMPs in a rat model [9]. Also in rat, an adenoviral vector carrying BMP-6 (AdBMP-6) produced more rapid tissue calcification and induced bone formation by both intramembranous and endochondral ossification compared to an adenoviral vector containing BMP-2 (AdBMP-2) or BMP-4 (AdBMP-4) [62]. Although these model studies suggest an effect of BMP-4 and BMP- 6 on fracture healing, the osteogenic activity of these BMPs has not yet adequately been investigated in humans (Table 1). Recently, BMP-6 displayed significantly more pronounced BMP reporter activation, osteoblast differentiation and stimulation of fracture healing than the most closely related family member BMP-7 [19, 63]. The higher ultimate effect is not due to the stimulating potential of BMP-6, but due to differences in the noggin-mediated negative feedback loop induced by these BMPs. Upon siRNA-mediated knockdown of noggin, BMP-7 appeared to be as effective in inducing BMP reporter activation and osteoblast differentiation as BMP-6. BMP-6 stimulation not only resulted in lower induction of noggin expression compared to BMP-7, but BMP-6 was also found to be almost insensitive to noggin-mediated inhibition. A lysine at position 60 (Lys60) was identified as a key residue conferring noggin resistance within the BMP-6 protein, and introducing a lysine residue at the position corresponding to BMP-6 Lys60 in BMP-7 and BMP-2 made these mutants more resistant to inhibition by noggin. Interestingly, BMP-9 also contains a lysine residue at this position and is, like BMP-6, not inhibited by noggin $[18,19]$. BMP-9 also emerged as one of the most potent inducers of osteogenic differentiation $[9,17,36,61,64,65]$. BMP-9 was shown to promote chondrogenic lineage differentiation of human multipotent mesenchymal cells. BMP-9 was more potent to maintain the expression of chondrocyte-specific extracellular matrix molecules than BMP-2 [66]. Combined injection in mice of BMP-9 and BMP-3, a known inhibitor of BMPs, resulted in the formation of bone, indicating that BMP-3 did not have the inhibiting effect which it has on other BMPs [61]. The highly increased osteogenic activity observed with BMP-9 may be due to the fact that it is not affected by BMP
Table 2 Properties of several BMPs. The resistance to noggin is caused by a lysine residue at position 60 in the molecule. Also the ability to induce differentiation in pluripotent and preosteoblastic cells is described. The possible induction of mineralised matrix by the different BMPs is described. The potency of superior BMPs with reference to less potent BMPs is explained

\begin{tabular}{|c|c|c|c|c|}
\hline & BMP-2 & BMP-6 & BMP-7 & BMP-9 \\
\hline Resistance to noggin & No $[18,19]$ & Yes [19] & No [19] & Yes $[18,19]$ \\
\hline $\begin{array}{l}\text { Inducing differentiation in } \\
\text { stem cells [17] }\end{array}$ & $\begin{array}{l}\text { Notable increase } \\
\text { in induction }\end{array}$ & $\begin{array}{l}\text { Notable increase } \\
\text { in induction }\end{array}$ & $\begin{array}{l}\text { Detectable, but marginal } \\
\text { induction }\end{array}$ & Notable increase in induction \\
\hline $\begin{array}{l}\text { Inducing differentiation in } \\
\text { preosteoblastic cells [17] }\end{array}$ & $\begin{array}{l}\text { Marked increase } \\
\text { in induction }\end{array}$ & $\begin{array}{l}\text { Marked increase } \\
\text { in induction }\end{array}$ & $\begin{array}{l}\text { Increase of induction at } \\
\text { later time point }\end{array}$ & Marked increase in induction \\
\hline $\begin{array}{l}\text { Induction of mineralised } \\
\text { matrix [17] }\end{array}$ & $\begin{array}{l}\text { Readily } \\
\text { detectable nodules }\end{array}$ & $\begin{array}{l}\text { Readily detectable } \\
\text { nodules }\end{array}$ & $\begin{array}{l}\text { Sparse, but detectable } \\
\text { nodules }\end{array}$ & Readily detectable nodules \\
\hline $\begin{array}{l}\text { Specific BMP more potent } \\
\text { than other BMPs }\end{array}$ & & $\begin{array}{l}\text { More potent than } \\
\text { BMP-2 [62] }\end{array}$ & & $\begin{array}{l}\text { Higher induction of expression with } \\
\text { specific molecules than BMP-2 [66] }\end{array}$ \\
\hline
\end{tabular}


antagonists such as noggin and BMP-3, essentially removing the negative feedback loop. Alternatively, it is possible to engineer BMP variants, such as variants of the currently used BMP-2 and BMP-7, with increased noggin resistance by substituting the amino acid residue corresponding to BMP-6 Lys-60 for a lysine residue. An alternative for the current treatment with BMP-2 or BMP-7 homodimers, the use of BMP-2/7 heterodimers could also be considered. These heterodimers display increased osteogenic potential and improved fusion compared with BMP homodimers [67]. Interestingly, BMP-2/7 heterodimers were found to induce lower levels of noggin expression and to be almost insensitive to noggin inhibition [68]. Recently, heterodimers of BMP-2/6 have been shown to bind more strongly to BMP receptors and are more osteogenic than BMP-2 [69].

Finally, another approach to enhance BMP-induced bone formation might be a combination with TGF- $\beta$. TGF- $\beta$ is generally considered to inhibit BMP signalling $[70,71]$. However, recently we demonstrated that the inhibitory effects of TGF- $\beta$ on BMP-induced osteoblast differentiation depend on the timing and environmental conditions of the co-stimulation, and that under well-controlled conditions, transient co-application of TGF- $\beta$ can actually promote BMP-induced differentiation towards the osteoblast lineage [72]. Co-application of TGF- $\beta 1$ with BMP-2 has been shown to accelerate bone formation, to increase total bone volume and to improve fracture healing in mice compared to application of BMP-2 alone [73]. Since TGF$\beta$ seems to stimulate early BMP-induced osteoblast differentiation whereas it inhibits late osteoblast differentiation and mineralisation, it can be considered to initially combine BMP and TGF- $\beta$ treatment followed by application of TGF- $\beta$ antagonists to enhance the bone fracture healing process.

\section{Conclusion}

The efficacy of the use of BMPs to enhance fracture healing is still controversial. The BMPs currently used to enhance bone fracture healing, rhBMP-2 and rhBMP-7, are expensive and have side effects. Other BMPs, such as BMP-6 and BMP-9, were shown to be more potent in vivo and might turn out to be more effective for the treatment of delayed and non-union fractures. As a consequence of the resistance of BMP-6 and BMP-9 to noggin-mediated inhibition, lower, more physiological amounts of these BMPs will be needed to improve fracture healing. Optimisation of the BMP products used and cheaper production methods will inevitably stimulate the clinical use of BMPs for bone fracture healing. A lot of questions still have to be solved to establish when and where the use of BMPs is the most profitable and effective.
Acknowledgements Dr. D.J.J. de Gorter is financially supported by a grant from The Netherlands Organization for Health Research (NWO 916.66.606).

Conflict of interest The authors declare that they have no conflict of interest.

Open Access This article is distributed under the terms of the Creative Commons Attribution Noncommercial License which permits any noncommercial use, distribution, and reproduction in any medium, provided the original author(s) and source are credited.

\section{References}

1. Meling T, Harboe K, Søreide K (2009) Incidence of traumatic longbone fractures requiring in-hospital management: a prospective ageand gender-specific analysis of 4890 fractures. Injury 40:1212-1219

2. Tosounidis T, Kontakis G, Nikolaou V, Papathanassopoulos A, Giannoudis PV (2009) Fracture healing and bone repair: an update. Trauma 11:145-156

3. Court-Brown CM, Bucholz RW, Heckman JD (2005) Fractures of the tibia and fibula. Rockwood and Green's fractures in adults. Lippincott Williams \& Wilkins, Philadelphia, pp 2079-2146

4. Dimitriou R, Tsiridis E, Giannoudis PV (2005) Current concepts of molecular aspects of bone healing. Injury 36:1392-1404

5. Komatsu DE, Warden SJ (2010) The control of fracture healing and its therapeutic targeting: improving upon nature. $\mathrm{J}$ Cell Biochem 109:302-311

6. Urist MR (1965) Bone: formation by autoinduction. Science 150:893-899

7. Wozney JM, Rosen V, Celeste AJ, Mitsock LM, Whitters MJ, Kriz RW, Hewick RM, Wang EA (1988) Novel regulators of bone formation: molecular clones and activities. Science 242:1528-1534

8. Vukicević S, Stavljenić A, Pećina M (1995) Discovery and clinical applications of bone morphogenetic proteins. Eur J Clin Chem Clin Biochem 33:661-671

9. Li JZ, Li H, Sasaki T, Holman D, Beres B, Dumont RJ, Pittman DD, Hankins GR, Helm GA (2003) Osteogenic potential of five different recombinant human bone morphogenetic protein adenoviral vectors in the rat. Gene Ther 10:1735-1743

10. Tsiridis E, Upadhyay N, Giannoudis P (2007) Molecular aspects of fracture healing: which are the important molecules? Injury 38 (Suppl 1):S11-S25

11. Miyazono K, Kamiya Y, Morikawa M (2010) Bone morphogenetic protein receptors and signal transduction. J Biochem 147:35-51

12. Kessler E, Takahara K, Biniaminov L, Brusel M, Greenspan DS (1996) Bone morphogenetic protein-1: the type I procollagen Cproteinase. Science 271:360-362

13. Daluiski A, Engstrand T, Bahamonde ME, Gamer LW, Agius E, Stevenson SL, Cox K, Rosen V, Lyons KM (2001) Bone morphogenetic protein-3 is a negative regulator of bone density. Nat Genet 27:84-88

14. Shen B, Bhargav D, Wei A, Williams LA, Tao H, Ma DD, Diwan AD (2009) BMP-13 emerges as a potential inhibitor of bone formation. Int J Biol Sci 5:192-200

15. Sipe JB, Zhang J, Waits C, Skikne B, Garimella R, Anderson HC (2004) Localization of bone morphogenetic proteins (BMPs)-2, -4, and -6 within megakaryocytes and platelets. Bone $35: 1316-1322$

16. Pecina M, Vukicevic S (2007) Biological aspects of bone, cartilage and tendon regeneration. Int Orthop 31:719-720

17. Cheng H, Jiang W, Phillips FM, Haydon RC, Peng Y, Zhou L, Luu HH, An N, Breyer B, Vanichakarn P, Szatkowski JP, Park JY, He TC (2003) 
Osteogenic activity of the fourteen types of human bone morphogenetic proteins (BMPs). J Bone Joint Surg Am 85-A:1544-1552

18. Rosen V (2006) BMP and BMP inhibitors in bone. Ann N YAcad Sci 1068:19-25

19. Song K, Krause C, Shi S, Patterson M, Suto RK, Grgurevic L, Vukicevic S, van Dinther M, Falb D, Ten Dijke P, Alaoui-Ismaili $\mathrm{MH}$ (2010) Identification of a key residue mediating bone morphogenetic protein (BMP)-6 resistance to noggin inhibition allows for engineered BMPs with superior agonist activity. J Biol Chem 285:12169-12180

20. Cunningham NS, Jenkins NA, Gilbert DJ, Copeland NG, Reddi AH, Lee SJ (1995) Growth/differentiation factor-10: a new member of the transforming growth factor-beta superfamily related to bone morphogenetic protein-3. Growth Factors 12:99-109

21. Dimitriou R, Tsiridis E, Carr I, Simpson H, Giannoudis PV (2006) The role of inhibitory molecules in fracture healing. Injury 37 (Suppl 1):S20-S29

22. Heinke J, Wehofsits L, Zhou Q, Zoeller C, Baar KM, Helbing T, Laib A, Augustin H, Bode C, Patterson C, Moser M (2008) BMPER is an endothelial cell regulator and controls bone morphogenetic protein-4-dependent angiogenesis. Circ Res 103:804-812

23. Dean DB, Watson JT, Moed BR, Zhang Z (2009) Role of bone morphogenetic proteins and their antagonists in healing of bone fracture. Front Biosci 14:2878-2888

24. Tsialogiannis E, Polyzois I, Oak Tang Q, Pavlou G, Tsiridis E, Heliotis M, Tsiridis E (2009) Targeting bone morphogenetic protein antagonists: in vitro and in vivo evidence of their role in bone metabolism. Expert Opin Ther Targets 13:123-137

25. Gamer LW, Cox K, Carlo JM, Rosen V (2009) Overexpression of BMP3 in the developing skeleton alters endochondral bone formation resulting in spontaneous rib fractures. Dev Dyn 238:2374-2381

26. Wilkinson L, Kolle G, Wen D, Piper M, Scott J, Little M (2003) CRIM1 regulates the rate of processing and delivery of bone morphogenetic proteins to the cell surface. J Biol Chem 278:34181-34188

27. Onichtchouk D, Chen YG, Dosch R, Gawantka V, Delius H, Massagué J, Niehrs C (1999) Silencing of TGF-beta signalling by the pseudoreceptor BAMBI. Nature 401:480-485

28. Ishibashi O, Ikegame M, Takizawa F, Yoshizawa T, Moksed MA, Iizawa F, Mera H, Matsuda A, Kawashima H (2010) Endoglin is involved in BMP-2-induced osteogenic differentiation of periodontal ligament cells through a pathway independent of Smad-1/ 5/8 phosphorylation. J Cell Physiol 222:465-473

29. Pardali E, van der Schaft DW, Wiercinska E, Gorter A, Hogendoorn PC, Griffioen AW, ten Dijke P (2011) Critical role of endoglin in tumor cell plasticity of Ewing sarcoma and melanoma. Oncogene 30:334-345

30. Sapkota G, Alarcón C, Spagnoli FM, Brivanlou AH, Massagué J (2007) Balancing BMP signaling through integrated inputs into the Smad1 linker. Mol Cell 25:441-454

31. Fuentealba LC, Eivers E, Ikeda A, Hurtado C, Kuroda H, Pera EM, De Robertis EM (2007) Integrating patterning signals: Wnt/ GSK3 regulates the duration of the BMP/Smad1 signal. Cell 131:980-993

32. Govender S, Csimma C, Genant HK, Valentin-Opran A, Amit Y, Arbel R, Aro H, Atar D, Bishay M, Börner MG, Chiron P, Choong P, Cinats J, Courtenay B, Feibel R, Geulette B, Gravel C, Haas N, Raschke M, Hammacher E, van der Velde D, Hardy P, Holt M, Josten C, Ketterl RL, Lindeque B, Lob G, Mathevon H, McCoy G, Marsh D, Miller R, Munting E, Oevre S, Nordsletten L, Patel A, Pohl A, Rennie W, Reynders P, Rommens PM, Rondia J, Rossouw WC, Daneel PJ, Ruff S, Rüter A, Santavirta S, Schildhauer TA, Gekle C, Schnettler R, Segal D, Seiler H, Snowdowne RB, Stapert J, Taglang G, Verdonk R, Vogels L, Weckbach A, Wentzensen A, Wisniewski T et al (2002) Recom- binant human bone morphogenetic protein-2 for treatment of open tibial fractures: a prospective, controlled, randomized study of four hundred and fifty patients. J Bone Joint Surg Am 84-A:21232134

33. Calori GM, Tagliabue L, Gala L, d'Imporzano M, Peretti g, Albisetti W (2008) Application of rhBMP-7 and platelet-rich plasma in the treatment of long bone non-unions: a prospective randomised clinical study on 120 patients. Injury 39:1391-1402

34. Giannoudis PV, Tzioupis C (2005) Clinical applications of BMP7: the UK perspective. Injury 36(Suppl 3):S47-S50

35. Katayama Y, Matsuyama Y, Yoshihara H, Sakai Y, Nakamura H, Imagama S, Ito Z, Wakao N, Kamiya M, Yukawa Y, Kanemura T, Sato K, Iwata H, Ishiguro N (2009) Clinical and radiographic outcomes of posterolateral lumbar spine fusion in humans using recombinant human bone morphogenetic protein-2: an average five-year follow-up study. Int Orthop 33:1061-1067

36. Varady P, Li JZ, Cunningham M, Beres EJ, Das S, Engh J, Alden TD, Pittman DD, Kerns KM, Kallmes DF, Helm GA (2001) Morphologic analysis of BMP-9 gene therapy-induced osteogenesis. Hum Gene Ther 12:697-710

37. Yilgor P, Hasirci N, Hasirci V (2010) Sequential BMP-2/BMP-7 delivery from polyester nanocapsules. J Biomed Mater Res A 93:528-536

38. Boerckel JD, Kolambkar YM, Dupont KM, Uhrig BA, Phelps EA, Stevens HY, García AJ, Guldberg RE (2011) Effects of protein dose and delivery system on BMP-mediated bone regeneration. Biomaterials 32:5241-5251

39. Valentin-Opran A, Wozney J, Csimma C, Lilly L, Riedel GE (2002) Clinical evaluation of recombinant human bone morphogenetic protein-2. Clin Orthop Relat Res 395:110-120

40. White AP, Vaccaro AR, Hall JA, Whang PG, Friel BC, McKee MD (2007) Clinical applications of BMP-7/OP-1 in fractures, nonunions and spinal fusion. Int Orthop 31:735-741

41. Geesink RG, Hoefnagels NH, Bulstra SK (1999) Osteogenic activity of OP-1 bone morphogenetic protein (BMP-7) in a human fibular defect. J Bone Joint Surg Br 81:710-718

42. Bilic R, Simic P, Jelic M, Stern-Padovan R, Dodig D, van Meerdervoort HP, Martinovic S, Ivankovic D, Pecina M, Vukicevic S (2006) Osteogenic protein-1 (BMP-7) accelerates healing of scaphoid non-union with proximal pole sclerosis. Int Orthop 30:128-134

43. Ristiniemi J, Flinkkilä T, Hyvönen P, Lakovaara M, Pakarinen H, Jalovaara P (2007) RhBMP-7 accelerates the healing in distal tibial fractures treated by external fixation. J Bone Joint Surg Br 89:265-272

44. Barr T, McNamara AJ, Sándor GK, Clokie CM, Peel SA (2010) Comparison of the osteoinductivity of bioimplants containing recombinant human bone morphogenetic proteins 2 (Infuse) and 7 (OP-1). Oral Surg Oral Med Oral Pathol Oral Radiol Endod 109:531-540

45. Garrison KR, Shemilt I, Donell S, Ryder JJ, Mugford M, Harvey I, Song F, Alt V (2010) Bone morphogenetic protein (BMP) for fracture healing in adults. Cochrane Database Syst Rev 6: CD006950

46. Bishop GB, Einhorn TA (2007) Current and future clinical applications of bone morphogenetic proteins in orthopaedic trauma surgery. Int Orthop 31:721-727

47. Mines D, Gu Y, Kou TD, Cooper GS (2011) Recombinant human bone morphogenetic protein-2 and pancreatic cancer: a retrospective cohort study. Pharmacoepidemiol Drug Saf 20:111-118

48. Tazaki J, Murata M, Akazawa T, Yamamoto M, Ito K, Arisue M, Shibata T, Tabata Y (2009) BMP-2 release and dose-response studies in hydroxyapatite and beta-tricalcium phosphate. Biomed Mater Eng 19:141-146

49. Alt V, Haas H, Rauschmann MA, Carstens C, Franke J, Eicher A, Bitschnau A, Schnettler R (2006) Health-economic considerations 
for the use of BMP-2 for spinal surgery in Germany (in German). Z Orthop Ihre Grenzgeb 144:577-582

50. Dahabreh Z, Calori GM, Kanakaris NK, Nikolaou VS, Giannoudis PV (2009) A cost analysis of treatment of tibial fracture nonunion by bone grafting or bone morphogenetic protein-7. Int Orthop 33:14071414

51. Garrison KR, Donell S, Ryder J, Shemilt I, Mugford M, Harvey I, Song F (2007) Clinical effectiveness and cost-effectiveness of bone morphogenetic proteins in the non-healing of fractures and spinal fusion: a systematic review. Health Technol Assess 11:1150, iii-iv

52. Kanakaris NK, Giannoudis PV (2007) The health economics of the treatment of long-bone non-unions. Injury 38(Suppl 2):S77S 84

53. Jones AL, Bucholz RW, Bosse MJ, Mirza SK, Lyon TR, Webb LX, Pollak AN, Golden JD, Valentin-Opran A et al (2006) Recombinant human BMP-2 and allograft compared with autogenous bone graft for reconstruction of diaphyseal tibial fractures with cortical defects. A randomized, controlled trial. J Bone Joint Surg Am 88:1431-1441

54. Friedlaender GE, Perry CR, Cole JD, Cook SD, Cierny G, Muschler GF, Zych GA, Calhoun JH, LaForte AJ, Yin S (2001) Osteogenic protein-1 (bone morphogenetic protein-7) in the treatment of tibial nonunions. J Bone Joint Surg Am 83-A(Suppl 1):S151-S158

55. von Einem S, Schwarz E, Rudolph R (2010) A novel TWO-STEP renaturation procedure for efficient production of recombinant BMP-2. Protein Expr Purif 73:65-69

56. Mundy G, Garrett R, Harris S, Chan J, Chen D, Rossini G, Boyce B, Zhao M, Gutierrez G (1999) Stimulation of bone formation in vitro and in rodents by statins. Science 286:1946-1949

57. Pauly S, Luttosch F, Morawski M, Haas NP, Schmidmaier G, Wildemann B (2009) Simvastatin locally applied from a biodegradable coating of osteosynthetic implants improves fracture healing comparable to BMP-2 application. Bone 45:505-511

58. Rittenberg B, Partridge E, Baker G, Clokie C, Zohar R, Dennis JW, Tenenbaum HC (2005) Regulation of BMP-induced ectopic bone formation by Ahsg. J Orthop Res 23:653-662

59. Wan DC, Pomerantz JH, Brunet LJ, Kim JB, Chou YF, Wu BM, Harland R, Blau HM, Longaker MT (2007) Noggin suppression enhances in vitro osteogenesis and accelerates in vivo bone formation. J Biol Chem 282:26450-26459

60. Ten Dijke P, Krause C, De Gorter DJ, Lowik CW, Van Bezooijen RL (2008) Osteocyte-derived sclerostin inhibits bone formation: its role in bone morphogenetic protein and Wnt signaling. J Bone Joint Surg Am 90 Suppl 1:31-5

61. Kang Q, Sun MH, Cheng H, Peng Y, Montag AG, Deyrup AT, Jiang W, Luu HH, Luo J, Szatkowski JP, Vanichakarn P, Park JY, Li Y, Haydon RC, He TC (2004) Characterization of the distinct orthotopic bone-forming activity of 14 BMPs using recombinant adenovirus-mediated gene delivery. Gene Ther $11: 1312-1320$

62. Jane JA Jr, Dunford BA, Kron A, Pittman DD, Sasaki T, Li JZ, Li H, Alden TD, Dayoub H, Hankins GR, Kallmes DF, Helm GA (2002) Ectopic osteogenesis using adenoviral bone morphogenetic protein (BMP)-4 and BMP-6 gene transfer. Mol Ther 6:464-470

63. Grasser WA, Orlic I, Borovecki F, Riccardi KA, Simic P, Vukicevic S, Paralkar VM (2007) BMP-6 exerts its osteoinductive effect through activation of IGF-I and EGF pathways. Int Orthop 31:759-765

64. Helm GA, Alden TD, Beres EJ, Hudson SB, Das S, Engh JA, Pittman DD, Kerns KM, Kallmes DF (2000) Use of bone morphogenetic protein-9 gene therapy to induce spinal arthrodesis in the rodent. J Neurosurg 92:191-196

65. Dumont RJ, Dayoub H, Li JZ, Dumont AS, Kallmes DF, Hankins GR, Helm GA (2002) Ex vivo bone morphogenetic protein-9 gene therapy using human mesenchymal stem cells induces spinal fusion in rodents. Neurosurgery 51:1239-1244

66. Majumdar MK, Wang E, Morris EA (2001) BMP-2 and BMP-9 promotes chondrogenic differentiation of human multipotential mesenchymal cells and overcomes the inhibitory effect of IL-1. J Cell Physiol 189:275-284

67. Zhu W, Rawlins BA, Boachie-Adjei O, Myers ER, Arimizu J, Choi E, Lieberman JR, Crystal RG, Hidaka C (2004) Combined bone morphogenetic protein-2 and -7 gene transfer enhances osteoblastic differentiation and spine fusion in a rodent model. $\mathrm{J}$ Bone Miner Res 19:2021-2032

68. Zhu W, Kim J, Cheng C, Rawlins BA, Boachie-Adjei O, Crystal RG, Hidaka C (2006) Noggin regulation of bone morphogenetic protein (BMP) 2/7 heterodimer activity in vitro. Bone 39:61-71

69. Valera E, Isaacs MJ, Kawakami Y, Izpisúa Belmonte JC, Choe S (2010) BMP-2/6 heterodimer is more effective than BMP-2 or BMP-6 homodimers as inductor of differentiation of human embryonic stem cells. PLoS One 5:e11167

70. Alliston T, Choy L, Ducy P, Karsenty G, Derynck R (2001) TGFbeta-induced repression of CBFA1 by Smad3 decreases cbfa1 and osteocalcin expression and inhibits osteoblast differentiation. EMBO J 20:2254-2272

71. Maeda S, Hayashi M, Komiya S, Imamura T, Miyazono K (2004) Endogenous TGF-beta signaling suppresses maturation of osteoblastic mesenchymal cells. EMBO J 23:552-563

72. de Gorter DJ, van Dinther M, Korchynskyi O, ten Dijke P (2011) Biphasic effects of transforming growth factor-beta on bone morphogenetic protein-induced osteoblast differentiation. J Bone Miner Res 26:1178-1187

73. Tachi K, Takami M, Sato H, Mochizuki A, Zhao B, Miyamoto Y, Tsukasaki H, Inoue T, Shintani S, Koike T, Honda Y, Suzuki O, Baba K, Kamijo R (2011) Enhancement of bone morphogenetic protein-2-induced ectopic bone formation by transforming growth factor-beta1. Tissue Eng Part A 17:597-606

74. Cho TJ, Gerstenfeld LC, Einhorn TA (2002) Differential temporal expression of members of the transforming growth factor beta superfamily during murine fracture healing. J Bone Miner Res 17:513-520

75. Yu YY, Lieu S, Lu C, Miclau T, Marcucio RS, Colnot C (2010) Immunolocalization of BMPs, BMP antagonists, receptors, and effectors during fracture repair. Bone 46:841-851

76. Chen D, Zhao M, Mundy GR (2004) Bone morphogenetic proteins. Growth Factors 22:233-241

77. Vainio S, Karavanova I, Jowett A, Thesleff I (1993) Identification of BMP-4 as a signal mediating secondary induction between epithelial and mesenchymal tissues during early tooth development. Cell 75:45-58

78. Bessa PC, Cerqueira MT, Rada T, Gomes ME, Neves NM, Nobre A, Reis RL, Casal M (2009) Expression, purification and osteogenic bioactivity of recombinant human BMP-4, $-9,-10,-11$ and -14 . Protein Expr Purif 63:89-94

79. Kingsley DM, Bland AE, Grubber JM, Marker PC, Russell LB, Copeland NG, Jenkins NA (1992) The mouse short ear skeletal morphogenesis locus is associated with defects in a bone morphogenetic member of the TGF beta superfamily. Cell 71:399-410

80. Bobacz K, Gruber R, Soleiman A, Erlacher L, Smolen JS, Graninger WB (2003) Expression of bone morphogenetic protein 6 in healthy and osteoarthritic human articular chondrocytes and stimulation of matrix synthesis in vitro. Arthritis Rheum 48:25012508

81. Vukicevic S, Grgurevic L (2009) BMP-6 and mesenchymal stem cell differentiation. Cytokine Growth Factor Rev 20:441-448

82. Dudley AT, Lyons KM, Robertson EJ (1995) A requirement for bone morphogenetic protein-7 during development of the mammalian kidney and eye. Genes Dev 9:2795-2807 
83. Luo G, Hofmann C, Bronckers AL, Sohocki M, Bradley A, Karsenty G (1995) BMP-7 is an inducer of nephrogenesis, and is also required for eye development and skeletal patterning. Genes Dev 9:2808-2820

84. DiLeone RJ, King JA, Storm EE, Copeland NG, Jenkins NA, Kingsley DM (1997) The Bmp8 gene is expressed in developing skeletal tissue and maps near the Achondroplasia locus on mouse chromosome 4. Genomics 40:196-198

85. Song JJ, Celeste AJ, Kong FM, Jirtle RL, Rosen V, Thies RS (1995) Bone morphogenetic protein-9 binds to liver cells and stimulates proliferation. Endocrinology 136:4293-4297

86. López-Coviella I, Berse B, Krauss R, Thies RS, Blusztajn JK (2000) Induction and maintenance of the neuronal cholinergic phenotype in the central nervous system by BMP-9. Science 289:313-316

87. Scharpfenecker M, van Dinther M, Liu Z, van Bezooijen RL, Zhao Q, Pukac L, Löwik CW, ten Dijke P (2007) BMP-9 signals via ALK1 and inhibits bFGF-induced endothelial cell proliferation and VEGF-stimulated angiogenesis. J Cell Sci 120:964-972
88. Chen H, Shi S, Acosta L, Li W, Lu J, Bao S, Chen Z, Yang Z, Schneider MD, Chien KR, Conway SJ, Yoder MC, Haneline LS, Franco D, Shou W (2004) BMP10 is essential for maintaining cardiac growth during murine cardiogenesis. Development 131:2219-2231

89. Fu SC, Wong YP, Chan BP, Pau HM, Cheuk YC, Lee KM, Chan KM (2003) The roles of bone morphogenetic protein (BMP) 12 in stimulating the proliferation and matrix production of human patellar tendon fibroblasts. Life Sci 72:2965-2974

90. Storm EE, Huynh TV, Copeland NG, Jenkins NA, Kingsley DM, Lee SJ (1994) Limb alterations in brachypodism mice due to mutations in a new member of the TGF beta-superfamily. Nature 368:639-643

91. Dube JL, Wang P, Elvin J, Lyons KM, Celeste AJ, Matzuk MM (1998) The bone morphogenetic protein 15 gene is X-linked and expressed in oocytes. Mol Endocrinol 12:1809-1817

92. Feiner N, Begemann G, Renz AJ, Meyer A, Kuraku S (2009) The origin of bmp16, a novel Bmp2/4 relative, retained in teleost fish genomes. BMC Evol Biol 9:277 